\title{
Staphylococcus aureus Induces Shedding of IL-1RII in Monocytes and Neutrophils
}

\author{
Constanza Giai $^{a}$ Cintia D. Gonzalez ${ }^{a} \quad$ Florencia Sabbione $^{b} \quad$ Ailin Garofalo $^{a}$ \\ Diego Ojeda $^{c}$ Daniel O.Sordellia Analía S. Trevani ${ }^{b}$ Marisa I. Gómez ${ }^{a}$ \\ anstituto de Investigaciones en Microbiologia y Parasitologia Medica (IMPaM), Consejo Nacional de Investigaciones \\ Científicas y Técnicas, Universidad de Buenos Aires, ${ }^{b}$ Laboratorio de Inmunidad Innata, Instituto de Medicina \\ Experimental (IMEX), Consejo Nacional de Investigaciones Científicas y Técnicas, Academia Nacional de Medicina, \\ and 'Instituto de Investigaciones Biomedicas en Retrovirus y Sida (INBIRS), Consejo Nacional de Investigaciones \\ Cientificas y Tecnicas, Universidad de Buenos Aires, Buenos Aires, Argentina
}

\section{Key Words}

Staphylococcus aureus · Protein A · Shedding · IL-1RII ·

ADAM17

\begin{abstract}
Interleukin 1 (IL-1) $\beta$ is a critical cytokine that orchestrates host defenses against Staphylococcus aureus and is crucial for the eradication of bacteria. The production and action of IL-1 $\beta$ are regulated by multiple control pathways. Among them, IL-1RII (the type II IL-1 receptor) acts as a decoy receptor and has been shown to regulate the biological effects of IL-1 $\beta$. High levels of soluble IL-1RII are present in septic patients; however, the stimuli that regulate the expression and release of IL-1RII in pathological conditions are incompletely elucidated. In the present study, we demonstrated the ability of S. aureus and protein A to induce IL-1RII shedding in myeloid cells. The positive modulation of IL-1RII expression and cleavage was associated with the failure to detect IL-1 $\beta$ in response to $S$. aureus both in vitro and in vivo, suggesting that the soluble form of the receptor could be masking the availability of IL-1 $\beta$. The absence of detectable IL-1 $\beta$ was associated with low levels of inflammatory cytokines and chemokines known to be regulated by IL-1 $\beta$ and with increased
\end{abstract}

\section{KARGER}

E-Mail karger@karger.com

www.karger.com/jin bacterial persistence. Modulation of decoy receptors during systemic $S$. aureus infection is proposed as a new strategy used by this bacterium to evade the immune response.

(c) 2016 S. Karger AG, Basel

\section{Introduction}

Staphylococcus aureus is a human pathogen that can cause localized infections, such as soft-tissue abscesses, as well as life-threatening systemic diseases, such as sepsis [1]. The increasing worldwide prevalence of antibioticresistant isolates and the rising incidence of severe sepsis and septic shock caused by this microorganism have become a serious public health concern [2].

Staphylococcal infections are usually characterized by a profound inflammatory response. Among the proinflammatory cytokines produced, IL- $1 \beta$ is a key cytokine that orchestrates host defenses against $S$. aureus and is crucial for the eradication of bacteria in several experimental models [3, 4]. However, this cytokine may be

C.D.G. and F.S. contributed equally to this work. (c) 2016 S. Karger AG, Basel

$1662-811 X / 16 / 0083-0284 \$ 39.50 / 0$
Dr. Marisa I. Gómez

Instituto de Investigaciones en Microbiología y Parasitología Médica (IMPaM) Consejo Nacional de Investigaciones Científicas y Técnicas

Universidad de Buenos Aires, Paraguay 2155, Buenos Aires C1121ABG (Argentina)

E-Mail marisaigomez@gmail.com 
harmful to the host if it is produced in excessive amounts or for extended periods of time [5,6]. Increased levels of IL- $1 \beta$ have been reported in experimental animal models and in human subjects with sepsis or shock, $[3,7]$ and they were often associated with organ damage, morbidity and mortality [7]. Therefore, the production, secretion and action of IL- $1 \beta$ are finely regulated by multiple control pathways [8]. IL- $1 \beta$ binds to two types of cellsurface receptors, IL-1RI (the type I IL-1 receptor), broadly expressed in host cells and responsible for intracellular signal transduction [9], and IL-1RII (the type II IL-1 receptor), which is expressed mainly by neutrophils, monocytes, B cells and bone marrow progenitor cells, and lacks a signaling domain [10]. In contrast to the IL$1 \mathrm{RI}$, type II receptors bind to IL- $1 \beta$ and prevent its interaction with type I receptors, therefore acting as decoy, dominant-negative molecules and scavengers [10]. IL$1 \mathrm{RII}$ also regulates the proinflammatory activities of IL$1 \beta$ by capturing the accessory protein and thus inhibiting the formation of the heterodimeric signaling complex with IL-1RI [10].

IL-1RII can be proteolytically processed and released in a soluble form via the action of ADAM17 [11-14] or alpha, beta and gamma secretases [15]. Moreover, a splice variant of the soluble IL-1RII (sIL-1RII) has been demonstrated [10]. Similarly to the membrane-bound form, sIL1 RII inhibits IL- $1 \beta$ activity by competing with the cellular IL-1RI for IL- $1 \beta$ binding. Basal levels of sIL-1RII are normally present in the plasma of healthy individuals, suggesting that they might serve to control any transient increase in IL- $1 \beta$ secretion [10]. Defective or increased expression of tissue or body fluid levels of sIL-1RII have been described in diverse pathological conditions [10]. However, how the expression and release of sIL-1RII is regulated by diverse stimuli is not completely understood.

Among the many factors that determine the pathogenicity of S. aureus, protein A acts as an exceptionally complex virulence factor, contributing to evasion of immune clearance and also inducing inflammation [16-20]. We have previously demonstrated that $S$. aureus protein A activates ADAM17 in airway epithelial cells and macrophages $[21,22]$ and induces shedding of TNFR1 [19, 2123] and IL-6R [24], and that both mechanisms act to counteract the proinflammatory action of TNF- $\alpha$ and IL6. Therefore, this study was aimed at investigating the ability of $S$. aureus and protein A to induce IL-1RII shedding in myeloid cells and its potential role in the regulation of IL-1 $\beta$ availability during systemic staphylococcal infection.

S. aureus Induces IL-1RII Shedding

\section{Materials and Methods}

\section{Recombinant Proteins and Bacterial Strains}

Full-length protein A cloned from S. aureus strain Newman, the IgG-binding domains (E-C region), the carboxyl-terminal polymorphic region $(\mathrm{X})$, the IgG-binding domain $\mathrm{D}$ and its corresponding L17A mutant were expressed as GST fusion proteins in E. coli BL21 and purified as described previously [22]. The recombinant proteins were dialyzed against PBS and used at a concentration of $2.5 \mu \mathrm{M}$ for in vitro stimulation. Potentially remaining lipopolysaccharide (LPS) traces were removed using Detoxi-Gel Endotoxin Removing Gel columns (Pierce, Holmdel, N.J., USA). The proteins were proven to be free of LPS by testing their stimulatory capacity in the presence or absence of polymyxin B.

$S$. aureus strain Newman and the isogenic protein A-deficient $\left(\mathrm{SpA}^{-}\right)$mutant were grown in trypticase soy broth (Britania, Buenos Aires, Argentina) and suspended in RPMI 1640 medium (Life Technologies, Grand Island, N.Y., USA) at a concentration of $5 \times$ $10^{8} \mathrm{CFU} / \mathrm{ml}$. S. aureus and the $\mathrm{SpA}{ }^{-}$mutant have the same replication time. Lactococcus lactis MG1363 carrying the pKS80 vector containing the full-length spa or an empty vector control (provided by Dr. Tim Foster, Trinity College, Dublin, Ireland) were grown in M17 medium supplemented with $0.5 \%$ glucose and $5 \mu \mathrm{g} /$ $\mathrm{ml}$ erythromycin at $30^{\circ} \mathrm{C}$ without agitation. Cells were harvested by centrifugation at $10,000 \mathrm{rpm}$ for $10 \mathrm{~min}$ and the pellet was suspended in RPMI 1640 medium (Life Technologies). L. lactis was inactivated by heating at $80^{\circ} \mathrm{C}$ in a water bath for $2 \mathrm{~h}$ and used at a concentration of $5 \times 10^{8} \mathrm{CFU} / \mathrm{ml}$.

\section{Cell Culture}

THP-1 cells (a human monocytic/macrophage cell line) were cultured in RPMI 1640 medium (Life Technologies) supplemented with $10 \%$ fetal bovine serum, $0.11 \mathrm{mg} / \mathrm{ml}$ sodium pyruvate (SigmaAldrich, St. Louis, Mo., USA), $0.29 \mathrm{mg} / \mathrm{ml}$ Glutamax (Life Technologies), $4.8 \mathrm{mM} \beta$-mercaptoethanol (Merck, Darmstadt, Germany) and $0.025 \%$ glucose (Britania). THP-1 cells were used at a final concentration of $10^{6}$ cells $/ \mathrm{ml}$ and stimulated with S. aureus at multiplicity of infection (MOI): 500 . When indicated, biochemical inhibitors were added $1 \mathrm{~h}$ prior to stimulation and during stimulation.

Human monocytes and neutrophils were purified from blood samples obtained from healthy donors under informed consent according to the Declaration of Helsinki by venipuncture of the forearm vein. Neutrophils were isolated from heparinized human blood by Ficoll-Triyosom (Ficoll: GE Healthcare, Munich, Germany; Triyosom: Bracco Imaging, Milan, Italy) gradient centrifugation and dextran (GE Healthcare) sedimentation, as previously described [25]. Contaminating erythrocytes were removed by hypotonic lysis. After washing, cell pellets were suspended in RPMI 1640 medium (Life Technologies) supplemented with $0.5 \%$ human serum albumin. Purity $>98 \%$ was confirmed by flow cytometry. Neutrophils were used at a final concentration of $5 \times$ $10^{6}$ cells $/ \mathrm{ml}$ and stimulated with S. aureus at MOI: 20. Monocytes were purified from peripheral blood mononuclear cells by using magnetic microbeads conjugated to monoclonal anti-CD14 antibodies (Miltenyi Biotec, Bergisch Gladbach, Germany) following the manufacturer's recommendations. Monocytes were resuspended in RPMI 1640 medium (Life Technologies) and supplemented with $10 \%$ fetal bovine serum. Purity $>98 \%$ was confirmed by flow cytometry. Monocytes were used at a final concentration of $10^{6}$ cells $/ \mathrm{ml}$ and stimulated with $S$. aureus at 
MOI: 500. Cell viability after stimulation was evaluated for the different cell types by propidium iodine staining and determined to be equivalent to $90 \%$.

\section{ELISA}

Human IL-1 $\beta$ and sIL-1RII in culture supernatants were quantified by ELISA using DuoSet antibody pairs (R\&D Systems, Minneapolis, Minn., USA). Mouse IL- $1 \beta$, IL-6, TNF- $\alpha$, IFN- $\gamma$, CXCL1, CXCL10 and MCP-1 were quantified in peritoneal fluid or plasma by ELISA using matched antibody pairs (mIL-1 $\beta$ : R\&D Systems; IL-6, TNF- $\alpha$, IFN- $\gamma$, CXCL1 and CXCL10: BD Biosciences, Franklin Lakes, N.J., USA; MCP-1: e-Bioscience, San Diego, Calif., USA).

\section{Flow Cytometry}

Human monocytes and neutrophils were washed twice with PBS and stained with phycoerythrin-labeled anti-IL-1RII (R\&D Systems). For murine neutrophil and monocyte/macrophage detection, peritoneal cell suspensions were stained with allophycocyanin-labeled anti-Ly6G (Biolegend, San Diego, Calif., USA) and phycoerythrin-labeled anti-F4/80 (Biolegend). The cells were washed, fixed in $1 \%$ paraformaldehyde and analyzed with a Becton Dickinson FACSCalibur. Data were collected using Cell Quest software and analyzed with Cyflogic. The populations were quantified based on fluorescent labeling and the FSC/SSC profile.

\section{In vivo Studies}

Six-week-old BALB/c mice obtained from the Department of Microbiology, School of Medicine, University of Buenos Aires animal facility were used. The mice were intraperitoneally inoculated with $0.2 \mathrm{ml}$ of a suspension of $S$. aureus or the SpA $\mathrm{A}^{-}$mutant containing $2 \times 10^{8} \mathrm{CFU} / \mathrm{ml}$. PBS was used for the control groups. Blood samples were obtained by puncture of the retro-orbital plexus at different times before and after inoculation. Plasma was stored at $-80^{\circ} \mathrm{C}$ for subsequent IL- $1 \beta$, IL- 6 and TNF- $\alpha$ quantification. Peritoneal lavages were collected using $8 \mathrm{ml}$ of cold RPMI 1640 media supplemented with $2 \%$ fetal bovine serum for RNA extraction, or using $2 \mathrm{ml}$ of cold PBS for bacterial counting, flow cytometry and cytokine/chemokine quantification. The animal studies were approved by the Institutional Committee for Care and Use of Laboratory Animals (CICUAL) of the School of Medicine, University of Buenos Aires, approval number 1101.

Real Time PCR

RNA was isolated using TRIzol Reagent (Life Technologies). cDNA was made from $1 \mu \mathrm{g}$ of RNA using ImProm-II reverse tran-

Fig. 1. Shedding of IL-1RII in response to S. aureus. a, b Expression of IL-1RII on the cell surface of naive human monocytes and neutrophils as determined by flow cytometry. Boxes and whiskers depict the percentage of cells positive for IL-1RII (a) and mean fluorescence intensity of IL-1RII (b). Data are presented as the maximum and minimum values obtained from individuals donors $(8$ per group), and the horizontal line represents the median for each group. c-j Monocytes (c, e-g) and neutrophils ( $\mathbf{d}, \mathbf{h}-\mathbf{j})$ were stimulated for up to $2 \mathrm{~h}$ with $S$. aureus or media alone, sIL-1RII in the supernatant was quantified by ELISA $(\mathbf{c}, \mathbf{d})$ and surface expression of IL-1RII was quantified by flow cytometry $(\mathbf{e}-\mathbf{j})$. c, $\mathbf{d}$ Boxes and whiskers depict maximum and minimum values obtained from scriptase (Promega, Fitchburg, Wis., USA). For quantitative realtime PCR, amplification was performed in an Applied Biosystems thermal cycler. The following primers were used for amplification: mouse IL- $1 \beta 5^{\prime}$-TTG ACA GTG ATG AGA ATG ACC- ${ }^{\prime}$ and $5^{\prime}$ CAA AGA TGA AGG AAA AGA AGG-3' , mouse IL-1RII $5^{\prime}$-GGT GCG GAC AAT GTT CAT CTT G- $3^{\prime}$ and $5^{\prime}$-GGG AAC TGC TGG AGA TGT CGG AGT G-3', mouse IL-1RI 5'-GAG TTA CCC GAG GTC CAG TGG- ${ }^{\prime}$ and $5^{\prime}$-GAG GGC TCA GGA TAA CAG G-3', mouse IL-1Ra 5'-AGA AGA AAA GAT AGA CAT GG- $3^{\prime}$ and $5^{\prime}$-ATA TCA TCT CCA GAC TTG G-3', and mouse GAPDH $5^{\prime}$-GAA GGT GGT GAA GCA GGC AT- $3^{\prime}$ and $5^{\prime}$-TCG AAG GTG GAA GAG TGG GA-3'. GAPDH was used as a control for standardization.

\section{Statistical Analysis}

Data from samples with a normal distribution were analyzed using the Student $t$ test. Data from samples that did not have a normal distribution were analyzed with the nonparametric Friedman test and Dunn's multiple comparison post hoc test, Wilcoxon matched-ranked test, Kruskal-Wallis test and Dunn's multiple comparison post hoc test, or Mann-Whitney test. The rate of bacteremia from in vivo studies was analyzed using Fisher's exact test. The nonparametric correlation Spearman test was used to analyze the correlation between the production of IL-1 $\beta$ and sIL-1RII. Graph Pad Prism Software version 4.0 was used. A p value $<0.05$ was considered statistically significant.

\section{Results}

\section{S. aureus Induces Shedding of IL-1RII in Myeloid Cells}

We first evaluated the expression of IL-1RII on the surface of human monocytes and neutrophils purified from peripheral blood. In agreement with previous findings $[10,11,26]$, IL-1RII was expressed at the surface of monocytes and neutrophils (fig. 1a, b). The percentage of cells expressing IL-1RII as well as the amount of receptor on the surface was higher in the neutrophil population than in monocytes (fig. 1a,b), although the differences were not statistically significant. In order to determine the ability of $S$. aureus to induce the shedding individual donors (10-11 per group) and the horizontal line represents the median for each group. ${ }^{* *} \mathrm{p}<0.01$, Wilcoxon matchedpairs signed rank test. The percentage of positive cells for IL-1RII $(\mathbf{e}, \mathbf{h})$ and mean fluorescence intensity (MFI) of IL-1RII (f, i) were determined by flow cytometry. Each pair of dots represents an individual donor. $\mathbf{g}, \mathbf{j}$ The change in IL-1RII expression at the cell surface $(\triangle \mathrm{MFI})$ was calculated for each individual donor as the IL1 RII expression in response to $S$. aureus minus the IL-1RII expression in response to media. Representative histograms are shown. Open histograms represent cells stained with antibody to IL-1RII, solid histograms represent controls.

(For figure see next page.) 
of IL-1RII, monocytes and neutrophils purified from peripheral blood were stimulated with $S$. aureus. A significant increase in the levels of sIL-1RII was observed at $2 \mathrm{~h}$ after stimulation in monocytes (fig. 1c) and neutrophils (fig. 1d). In monocytes, the increased levels of
sIL-1RII were associated with a decrease in the percentage of cells positive for IL-1RII (fig. 1e) as well as with diminished levels of receptor surface expression (fig. 1f, g). In neutrophils, the increased levels of sIL-1RII were associated with a decrease in the amount of receptor ex-
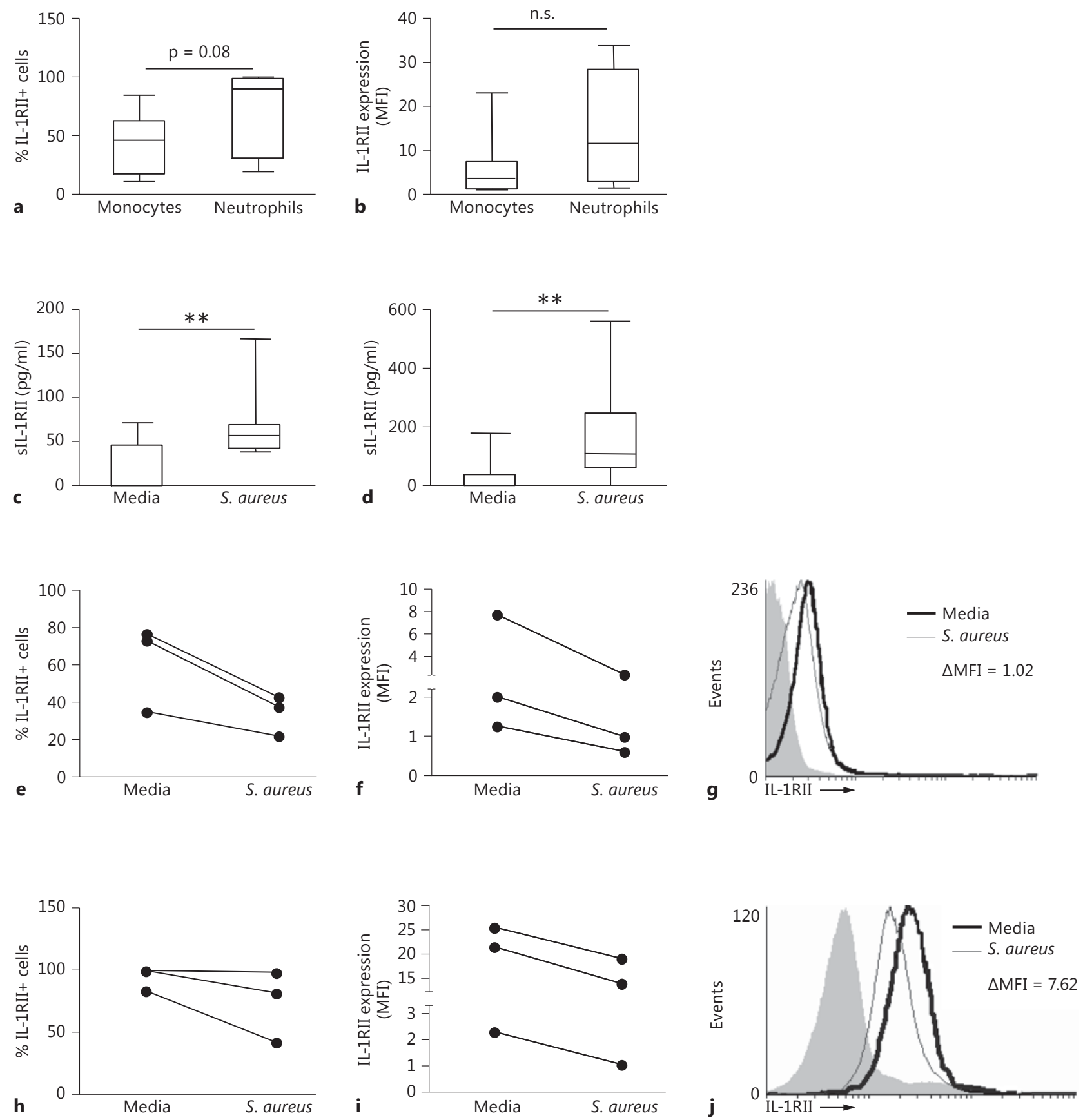

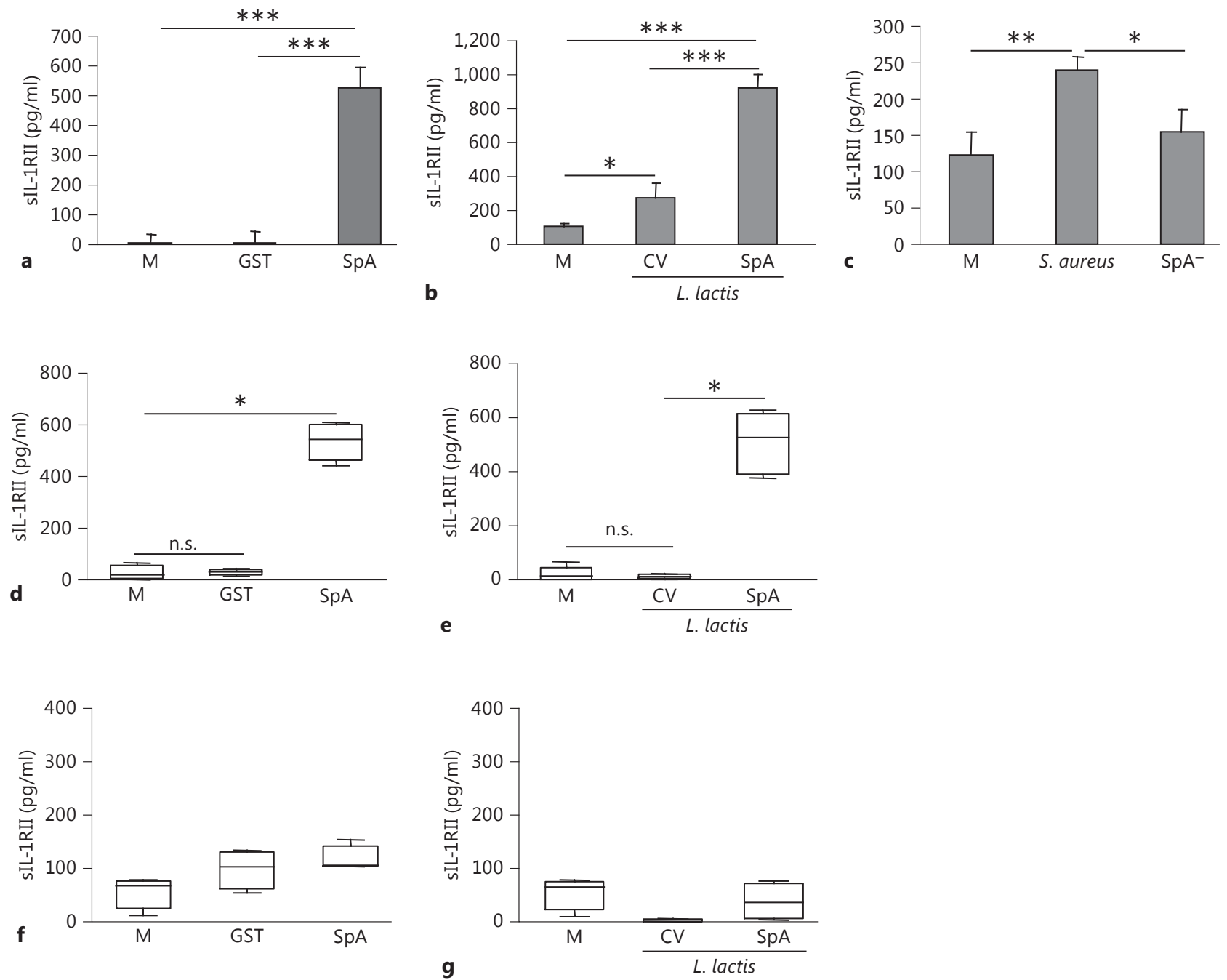

Fig. 2. Role of protein A in IL-1RII shedding by myeloid cells. THP-1 cells (a-c), monocytes (d, e) and neutrophils $(\mathbf{f}, \mathbf{g})$ were stimulated for 1 (a) or $2 \mathrm{~h}(\mathbf{b}-\mathbf{g})$ with full-length protein A (SpA), GST (as a control), L. lactis SpA, L. lactis containing a control vector (L. lactis $\mathrm{CV}$ ), wild-type $S$. aureus, the $\mathrm{SpA}^{-}$mutant or media alone, and sIL-1RII in the supernatant was quantified by ELISA. a-c Data are presented as the mean and standard deviation of trip- licate wells from 1 representative experiment out of 3 . $^{*} \mathrm{p}<0.05$; ${ }^{* *} \mathrm{p}<0.01{ }^{* * *} \mathrm{p}<0.001$, Student's t test. $\mathbf{d}-\mathbf{g}$ Boxes and whiskers depict maximum and minimum values obtained from individual donors (4-5 per group) and the horizontal line represents the median for each group. ${ }^{*} \mathrm{p}<0.05$, one-way ANOVA-Friedman's test with Dunn's post hoc test. pressed on the cell surface (fig. 1i, j), although the majority of the population continued to express IL-1RII (fig. 1h).

In order to assess the contribution of protein A to IL1RII release, THP-1 cells, monocytes and neutrophils were stimulated with recombinant protein $\mathrm{A}(\mathrm{SpA})$ and Lactococcus lactis-expressing protein A (L. lactis SpA). A significant increase in the levels of sIL-1RII released from
THP-1 cells (fig. 2a, b) and human monocytes (fig. 2d, e) was observed in response to both recombinant protein $\mathrm{A}$ and L. lactis SpA (fig. 2a, b, d, and e). Protein A, either purified or expressed at the surface of L. lactis, did not induce shedding of IL-1RII in neutrophils (fig. $2 \mathrm{f}, \mathrm{g}$ ). The role of protein A in IL-1RII shedding from monocytes was further confirmed by stimulating THP-1 cells with $S$. aureus or an $\mathrm{SpA}^{-}$mutant. The levels of sIL-1RII released 


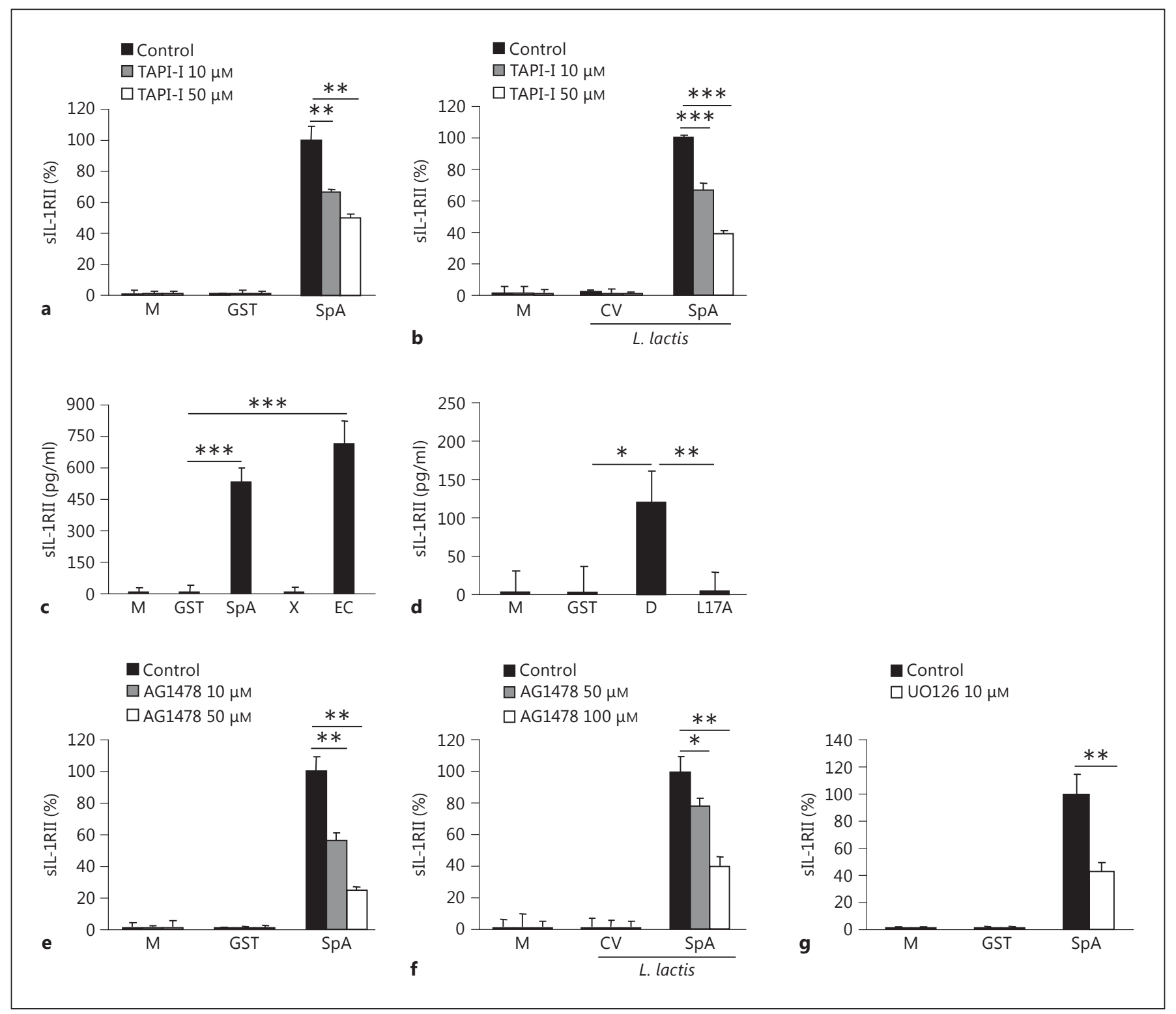

Fig. 3. Signaling cascades involved in the cleavage of IL-1RII. ag THP-1 cells were stimulated with full-length protein A (SpA), the amino-terminal portion of protein A (indicated as EC), the polymorphic region of $\mathrm{SpA}$ (indicated as X), the IgG-binding domain D, its corresponding L17A mutant (indicated as L17A), GST (as a control), L. lactis $\mathrm{SpA}, L$. lactis containing a control vector ( $L$. lactis $\mathrm{CV}$ ) or media alone in the absence (control) or presence of

in response to the $\mathrm{SpA}^{-}$mutant were significantly lower than those detected in response to $S$. aureus (fig. 2c). Taken together, these results demonstrate that $S$. aureus induces IL-1RII shedding by myeloid cells and that in monocytes the release of IL-1RII is highly dependent on protein A expression.

S. aureus Induces IL-1RII Shedding an ADAM17 inhibitor TAPI-I (a, b), an EGFR phosphorylation inhibitor AG1478 (e, f) and a erk1/2 phosphorylation inhibitor UO126 (g). The induction of sIL-1RII was determined at 1 (a, c-e, g) or $2 \mathrm{~h}(\mathbf{b}, \mathbf{f})$ after stimulation by ELISA. Data are presented as the mean and standard deviation of triplicate wells from 1 representative experiment out of $3 .{ }^{*} \mathrm{p}<0.05$; $^{* *} \mathrm{p}<0.01$; ${ }^{* * *} \mathrm{p}<0.001$, Student's t test.

Cleavage from the cell surface mediated by ADAM17 has been described as the major mechanism of sIL-1RII release $[12,14]$. We then investigated the role of ADAM17 in IL-1RII shedding induced by protein A in monocytes. The levels of sIL-1RII released in response to protein A or L. lactis SpA were significantly decreased in a dose-de- 
pendent manner in cells treated with a chemical inhibitor of ADAM17 (fig. 3a, b). We have previously demonstrated that the interaction of protein A with the epidermal growth factor receptor (EGFR) mediates ADAM17 activation and TNFR1 shedding in airway epithelial cells and immune cells $[21,22]$. Thus, we investigated whether the amino-terminal region of protein A known to interact with EGFR was involved in sIL-1RII production in monocytes. IL-1RII shedding was observed in monocytes stimulated with recombinant GST-tagged protein corresponding to the amino-terminal region of protein $\mathrm{A}$ containing the IgG-binding domains (EC fragment) as opposed to stimulation with the carboxy-terminal region (X fragment; fig. 3c). The interaction of the leucine 17 located in the conserved amino-terminal domains of protein $\mathrm{A}$ is necessary for EGFR recognition of protein A and the subsequent phosphorylation of ADAM17 in threonine by erk $1 / 2$ in airway epithelial cells and immune cells $[21,22]$. Thus, we next determined the role of protein AEGFR-mediated signaling in IL-1RII shedding from monocytes by using a mutated protein A (L17A). Cells stimulated with the L17A mutant did not produce sIL$1 \mathrm{RII}$, in contrast to the wild-type D domain (fig. $3 \mathrm{~d}$ ). Consistent with these findings, chemical inhibition of EGFR phosphorylation significantly reduced the levels of sIL$1 \mathrm{RII}$ induced in response to protein A and L. lactis SpA in a dose-dependent manner (fig. 3e, f) without affecting cell viability. Moreover, the levels of sIL-1RII were significantly decreased in cells stimulated with protein $\mathrm{A}$ in the presence of a chemical inhibitor of erk $1 / 2$ phosphorylation (fig. 3g). Taken together, these results indicate that protein A induces IL-1RII shedding by initiating EGFRmediated signaling and subsequent ADAM17 activation.

\section{IL-1RII Shedding Induced by S. aureus Precedes IL-1} Secretion

In order to characterize the kinetics of IL-1RII shedding, myeloid cells were stimulated for different periods of time with $S$. aureus and the levels of sIL-1RII in the culture supernatant were determined. A significant increase in sIL-1RII was observed in response to $S$. aureus in THP- 1 cells as early as 15 min after stimulation (fig. 4a). In human monocytes, the release of IL-1RII was observed starting at $1 \mathrm{~h}$ poststimulation (fig. $4 \mathrm{c}$ ). We then characterized the kinetics of IL- $1 \beta$ production by immune cells in response to $S$. aureus. Detectable levels of secreted IL$1 \beta$ were observed starting at 1 and $2 \mathrm{~h}$ after stimulation of THP- 1 cells and human monocytes, respectively (fig. $4 \mathrm{~b}$, d). These results demonstrate that in monocytes the appearance of sIL-1RII preceded IL-1 $\beta$ detection indicating an early production of sIL-1RII in comparison with the induction of inflammatory mediators. Moreover, at $2 \mathrm{~h}$ poststimulation, a time point in which both sIL-1RII and IL- $1 \beta$ were detected, there was an inverse correlation between the levels of receptor released and IL- $1 \beta$ analyzed for each individual donor (fig. 4e). Shedding of IL-1RII was observed starting at $2 \mathrm{~h}$ poststimulation in neutrophils (fig. 4f) and secreted IL- $1 \beta$ was detected at the same time point (fig. $4 \mathrm{~g}$ ), although the levels of this cytokine were lower than those produced by monocytes (fig. $4 \mathrm{~d}$ ). In addition, there was no correlation between the amount of sIL-1RII and IL-1 $\beta$ at a single donor level (fig. $4 \mathrm{~h}$ ).

\section{S. aureus Protein A Modulates IL-1RII Expression,} $I L-1 \beta$ Availability and Inflammation

We then evaluated IL-1RII and IL- $1 \beta$ expression during early $S$. aureus infection in vivo. Mice were inoculated by the intraperitoneal route with $S$. aureus, the $\mathrm{SpA}^{-}$mutant or PBS (control), and the levels of IL-1RII mRNA were quantified in peritoneal infiltrates. A significant increase in IL-1RII mRNA expression was observed in mice infected with $S$. aureus at $2 \mathrm{~h}$ postinoculation (fig. 5a). Although the expression of IL-RII was also induced after inoculation with the $\mathrm{SpA}^{-}$mutant, it was lower than that observed in mice inoculated with $S$. aureus and it did not significantly differ from control mice (fig. 5a). Transcription of IL-1RII had decreased by $4 \mathrm{~h}$ postinoculation in both groups (fig. 5a). S. aureus also induced a significant increase in the early expression of IL-1Ra, a molecule known to negatively regulate IL- $1 \beta$ signaling (fig. $5 \mathrm{~b}$ ). IL$1 \mathrm{RI}$ expression was increased in both groups at $2 \mathrm{~h}$ after inoculation (fig. 5c) whereas at $4 \mathrm{~h}$ it was only increased in the $\mathrm{SpA}^{-}$mutant-inoculated group (fig. 5c). The levels of IL- $1 \beta$ detected in the peritoneal fluid of mice inoculated with $S$. aureus at 2 and $4 \mathrm{~h}$ after challenge were lower than those detected in mice inoculated with the $\mathrm{SpA}^{-}$ mutant (fig. 5d). We confirmed that $S$. aureus infection was able to induce IL- $1 \beta$ production in vivo by quantifying IL- $1 \beta$ transcription in peritoneal infiltrates. A significant increase in the levels of IL- $1 \beta$ mRNA was observed in mice inoculated with $S$. aureus at $2 \mathrm{~h}$ after inoculation and with both strains at $4 \mathrm{~h}$ postinoculation (fig. 5e). Moreover, the levels of IL- $1 \beta$ mRNA expression induced at $2 \mathrm{~h}$ postinoculation were higher in mice inoculated with $S$. aureus compared with mice inoculated with the $\mathrm{SpA}^{-}$mutant (fig. 5e), indicating that the low levels of IL$1 \beta$ detected in the peritoneal fluid of $S$. aureus-inoculated mice was not due to a defect on IL- $1 \beta$ induction.

We then determined the consequences of protein $\mathrm{A}$ regulation of IL- $1 \beta$ availability during early $S$. aureus in- 

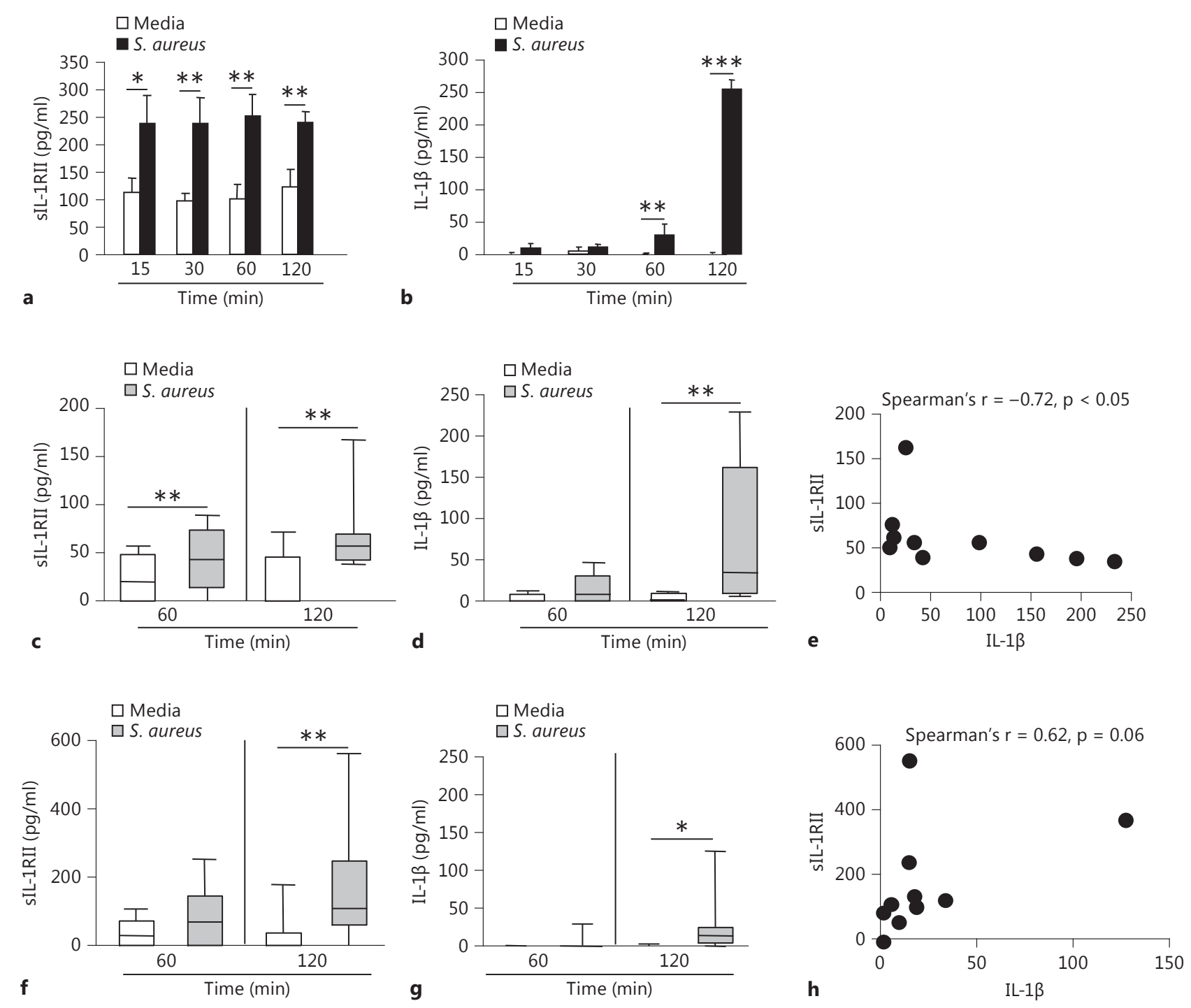

Fig. 4. Kinetics of IL-1 $\beta$ and sIL-1RII production in response to $S$. aureus. THP-1 cells $(\mathbf{a}, \mathbf{b})$, monocytes (c-e) and neutrophils $(\mathbf{f}-\mathbf{h})$ were stimulated for different periods of time with $S$. aureus or media alone and the induction of sIL-1RII $(\mathbf{a}, \mathbf{c}, \mathbf{f})$ and IL-1 $\beta(\mathbf{b}, \mathbf{d}, \mathbf{g})$ was determined by ELISA. $\mathbf{a}, \mathbf{b}$ Data are presented as the mean and standard deviation of triplicate wells from 1 representative experiment out of 3 . $^{*} \mathrm{p}<0.05$; $^{* *} \mathrm{p}<0.01$; $^{* *} \mathrm{p}<0.001$, Student's t test.

fection in the modulation of the local and systemic inflammatory response. The levels of inflammatory cytokines and chemokines in response to $S$. aureus challenge were quantified in the peritoneum. Increased levels of IL- 6 were observed at $2 \mathrm{~h}$ after inoculation with both the wild-type and the SpA- mutant (fig. 6a). However, at $4 \mathrm{~h}$ c, $\mathbf{d}, \mathbf{f}, \mathbf{g}$ Boxes and whiskers depict maximum and minimum values obtained from individual donors, $8-10$ per group, and the horizontal line represents the median for each group. ${ }^{*} \mathrm{p}<0.05$; ** $\mathrm{p}<0.01$, Wilcoxon matched-pairs signed rank test. e, $\mathbf{h}$ Correlation analysis of the induction of sIL-1RII versus IL- $1 \beta$ production at $2 \mathrm{~h}$ poststimulus with $S$. aureus.

after challenge, the levels of IL- 6 in mice inoculated with the $\mathrm{SpA}^{-}$mutant were significantly higher than those found in the S. aureus-inoculated group (fig. 6a). This cytokine returned to basal levels by $24 \mathrm{~h}$ after inoculation (data not shown). The levels of IFN- $\gamma$ in the peritoneum were only significantly increased in mice inoculated with 
Fig. 5. Expression of IL-1 family members during S. aureus infection. Mice were intraperitoneally inoculated with wild-type $S$. aureus, the SpA ${ }^{-}$mutant or PBS (control). IL-1RII (a), IL-1Ra (b) and IL-1RI (c) expression in peritoneal cells at the indicated time points after challenge was quantified by RT real-time PCR and normalized to GAPDH. Each dot represents an individual mouse and horizontal lines show the median value in each group. ${ }^{* *} \mathrm{p}<0.01$, Kruskal-Wallis test with Dunn's post hoc test for multiple comparisons. d IL- $1 \beta$ levels in peritoneal fluid were quantified by ELISA. Each dot represents an individual mouse and horizontal lines show the median value in each group (nonparametric MannWhitney test). e IL- $1 \beta$ expression in peritoneal cells at the indicated time points after challenge was quantified by RT realtime PCR and normalized to GAPDH. Each dot represents an individual mouse and horizontal lines show the median value in each group. ${ }^{*} \mathrm{p}<0.05 ;{ }^{* *} \mathrm{p}<0.01$, Kruskal-Wallis test with Dunn's post hoc test for multiple comparisons.

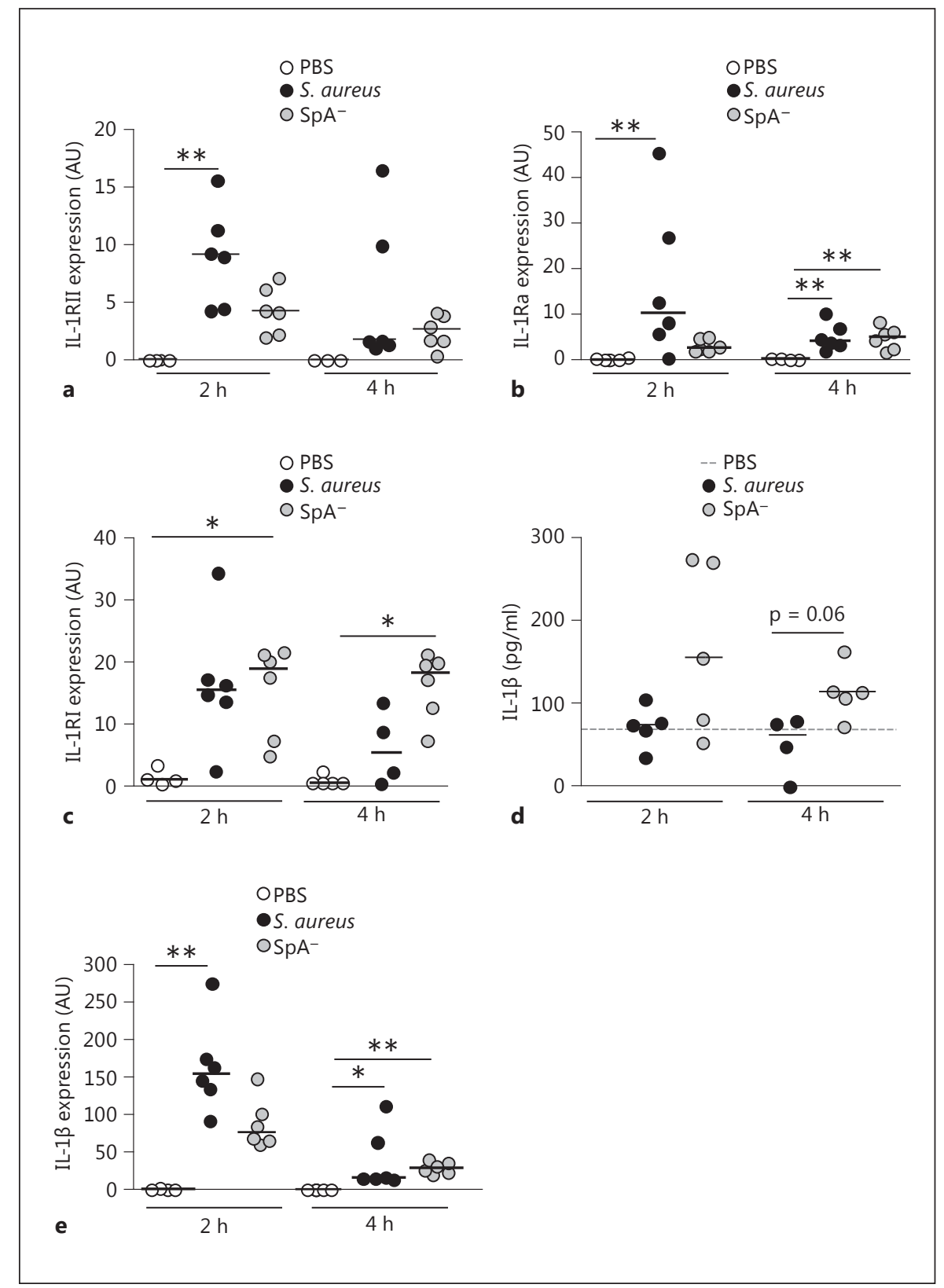

the $\mathrm{SpA}^{-}$mutant at $4 \mathrm{~h}$ after challenge (fig. $6 \mathrm{~b}$ ). CXCL1 levels were increased at $2 \mathrm{~h}$ after inoculation with both $S$. aureus and the $\mathrm{SpA}^{-}$mutant compared with mice inoculated with PBS as a control (fig. 6c). Two hours later, the levels of this chemokine were significantly reduced in mice inoculated with S. aureus (fig. 6c). Conversely, significantly increased levels of CXCL1 persisted at $4 \mathrm{~h}$ after challenge in mice inoculated with the $\mathrm{SpA}^{-}$mutant (fig. 6c). Moreover, at $24 \mathrm{~h}$, when CXCL1 levels had almost returned to basal values, there was a trend to in- creased production of this chemokine in mice inoculated with the $\mathrm{SpA}^{-}$mutant (fig. $6 \mathrm{c}$ ). The increased levels of IL- 6 and IFN- $\gamma$ as well as sustained production of CXCL1 in the $\mathrm{SpA}^{-}$-inoculated group could be explained by the increased levels of available IL-1 $\beta$ in these mice (fig. $5 c$ ), as has been previously described for the regulation of these inflammatory molecules [27-30]. We have previously reported that protein A induces CXCL10 production in macrophages [31]. The critical role of protein $\mathrm{A}$ in the induction of this chemokine in vivo was further con- 
Fig. 6. Peritoneal S. aureus infection. Mice were intraperitoneally inoculated with wild-type $S$. aureus, the $S p A^{-}$mutant or PBS (control). IL-6 (a), IFN- $\gamma$ (b), CXCL1 (c) and CXCL10 (d) levels in peritoneal fluid were quantified by ELISA. Each dot represents an individual mouse and horizontal lines show the median value in each group. * $\mathrm{p}<0.05$; ** $\mathrm{p}<0.01$, nonparametric Mann-Whitney test. The percentage of recruited neutrophils (e) and monocytes (f) as well as the ratio of neutrophils/monocytes $(\mathbf{g})$ in the peritoneum at $4 \mathrm{~h}$ after inoculation was determined by flow cytometry. Boxes and whiskers depict maximum and minimum values obtained from individual mice ( 5 per group) and the horizontal line represents the median for each group. ${ }^{*} \mathrm{p}<0.05$, nonparametric MannWhitney test. $\mathbf{h}$ Bacterial counts in peritoneum at 2 and $4 \mathrm{~h}$ postinoculation. Each box represents an individual group of mice and horizontal lines show the median value for each group. ${ }^{*} \mathrm{p}<0.05$, nonparametric Mann-Whitney test.

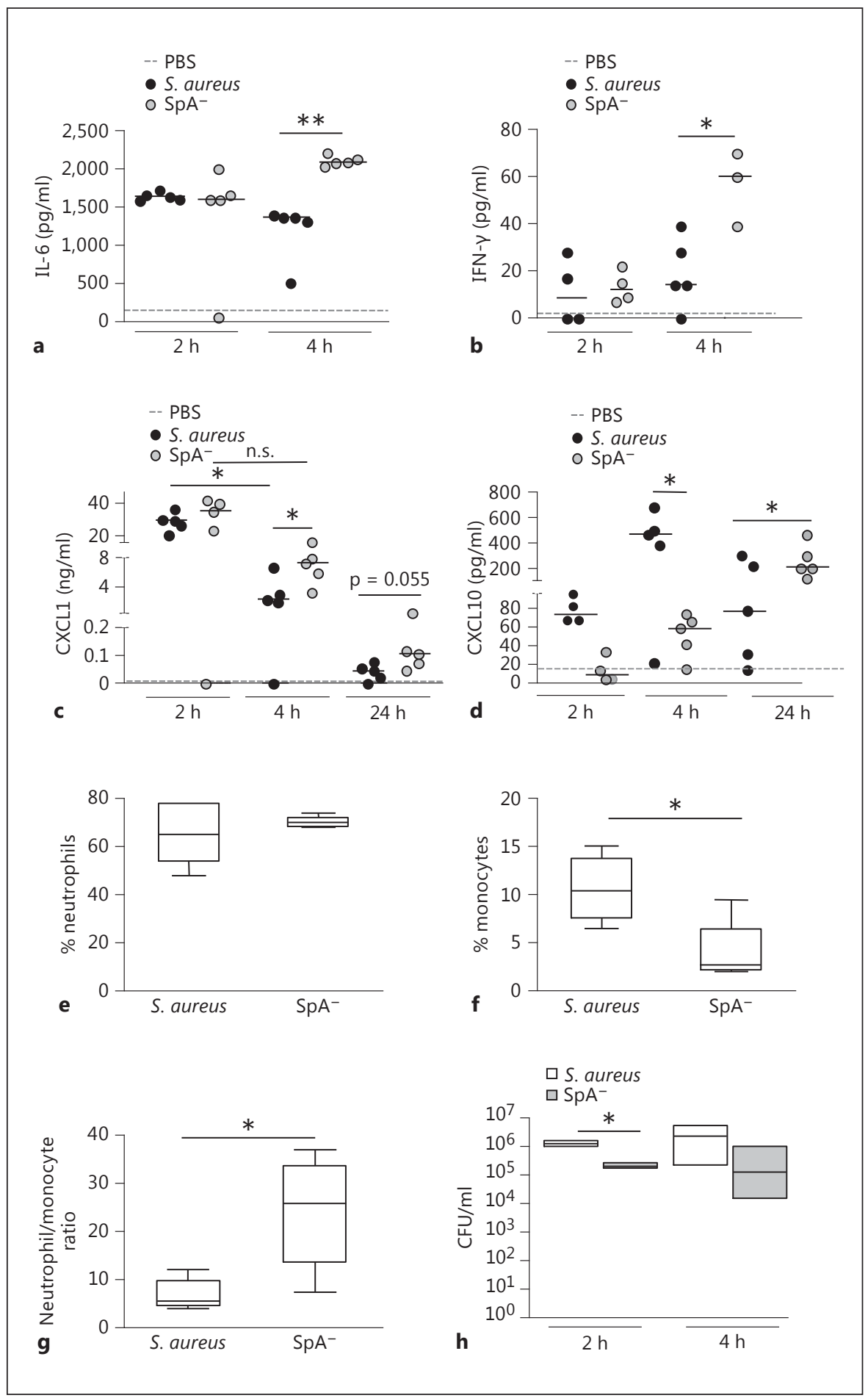

firmed in this study. CXCL10 was detected as early as $2 \mathrm{~h}$ after inoculation with $S$. aureus and it was significantly increased $2 \mathrm{~h}$ later (fig. $6 \mathrm{~d}$ ). Mice inoculated with the $\mathrm{SpA}^{-}$mutant had significantly reduced levels of CXCL10 at both time points (fig. $6 \mathrm{~d}$ ), confirming the role of pro- tein A in the early induction of this chemokine. The levels of CXCL10 in mice inoculated with $S$. aureus had decreased by $24 \mathrm{~h}$ (fig. 6d). Conversely, mice inoculated with the SpA- mutant showed significantly increased levels of CXCL10 at $24 \mathrm{~h}$ after inoculation compared with 


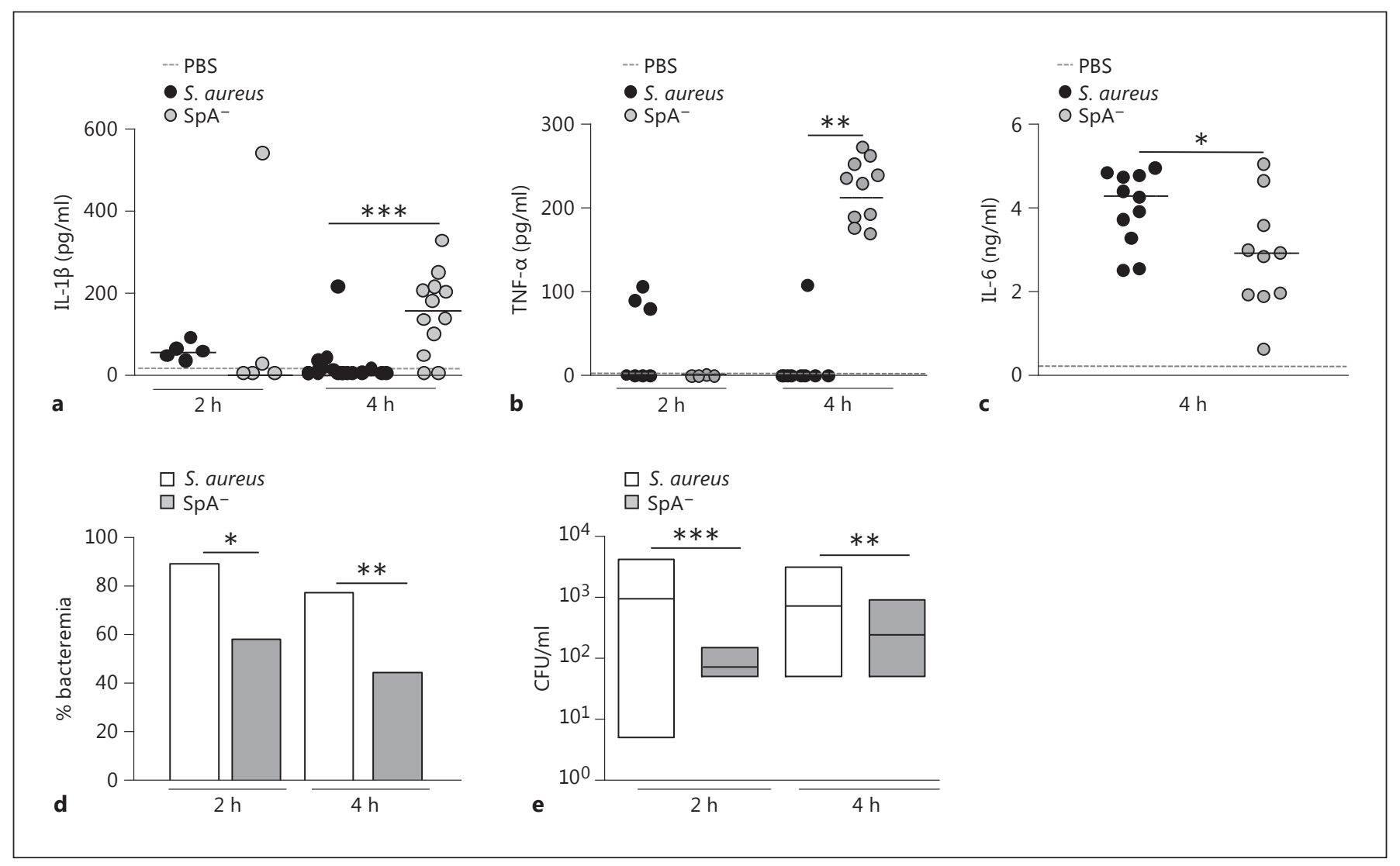

Fig. 7. S. aureus systemic infection. Mice were intraperitoneally inoculated with wild-type $S$. aureus, the $\mathrm{SpA}^{-}$mutant or PBS (control). IL-1 $\beta$ (a), TNF- $\alpha$ (b) and IL-6 (c) levels in serum were quantified by ELISA. Each dot represents an individual mouse and horizontal lines show the median value in each group. ${ }^{*} \mathrm{p}<0.05$; ** $\mathrm{p}<0.01$, nonparametric Mann-Whitney test. The rate of bacte- remia (d) and bacterial counts in blood from mice with positive culture (e) were determined at 2 and 4 h postinoculation. $\mathbf{d}$ Bars represent the percentage of bacteremia for each group. e Each box represents an individual group of mice and horizontal lines show the median value for each group. ${ }^{*} \mathrm{p}<0.05$; $^{* *} \mathrm{p}<0.01$; ${ }^{* * *} \mathrm{p}<$ 0.001 , nonparametric Mann-Whitney test and Fisher's exact test. those detected at $4 \mathrm{~h}$ after challenge (fig. $6 \mathrm{~d}$ ). The upregulation of CXCL10 in the SpA-inoculated mice at this time point could be explained by the combined action of IL- $1 \beta$ and IFN $-\gamma$, as has been previously reported $[27,32]$. The levels of TNF- $\alpha$ in peritoneal fluid were low and they did not significantly differ between infected and control mice at the times evaluated, whereas MCP-1 was not detected in any of the experimental groups (data not shown).

In order to further characterize the inflammatory response in the peritoneum, cellular infiltration was evaluated by flow cytometry. At $4 \mathrm{~h}$ after inoculation similar percentages of neutrophils were observed in S. aureus and $\mathrm{SpA}^{-}$mutant-inoculated mice (fig. 6e). In both groups resident macrophages were not detected, as has been previously described for early peritoneal inflammation [33]. A significant infiltration of newly recruited monocytes, cells known to be critical for the resolution of inflammation, was observed in $S$. aureus-inoculated mice compared with the $\mathrm{SpA}^{-}$mutant-inoculated group (fig. 6f). As a consequence, the ratio between neutrophils, cells responsible for bacterial killing, and monocytes was significantly lower in mice inoculated with $S$. aureus compared to that in mice inoculated with the $\mathrm{SpA}^{-}$mutant (fig. $6 \mathrm{~g}$ ). The amount of bacteria recovered from the peritoneum of mice at 2 and $4 \mathrm{~h}$ postinoculation was higher in those challenged with $S$. aureus than those inoculated with the $\mathrm{SpA}^{-}$mutant (fig. $6 \mathrm{~h}$ ), probably as a consequence of the lower neutrophil/monocyte ratio as well as the lower levels of cytokines critical for bacterial eradication present in the peritoneum of $S$. aureus-inoculated mice.

Similarly to the results observed in the peritoneum, a significant increase in the levels of circulating IL- $1 \beta$ was 
observed in mice challenged with the $\mathrm{SpA}^{-}$mutant at $4 \mathrm{~h}$ after inoculation, whereas this cytokine was not detected in sera from mice inoculated with S. aureus (fig. 7a). The levels of TNF- $\alpha$ were also significantly higher in mice inoculated with the SpA ${ }^{-}$mutant than those found in mice inoculated with S. aureus (fig. 7b), which is in accordance with our previous findings [22]. Although the levels of IL-6 were significantly lower in mice inoculated with the $\mathrm{SpA}^{-}$mutant, an important induction of this cytokine was observed at $4 \mathrm{~h}$ after inoculation in both groups (fig. 7c), consistent with a previously described role of this cytokine during S. aureus sepsis [34]. The analysis of leukocyte populations in blood during early $S$. aureus infection revealed that, between 2 and $4 \mathrm{~h}$ after inoculation, the percentage of neutrophils was double that found before challenge (median basal, 18\%; median after inoculation, $36 \%$ ), and no differences were observed compared with the $\mathrm{SpA}^{-}$mutant-inoculated mice (median basal, 19\%; median after inoculation, 33\%). In order to evaluate the consequences of the increased inflammatory status of mice inoculated with the $\mathrm{SpA}^{-}$mutant compared to those inoculated with $S$. aureus, the rate of bacteremia after challenge with both strains was determined. Decreased rates of bacteremia were observed in mice inoculated with the $\mathrm{SpA}^{-}$mutant compared to those inoculated with $S$. aureus at $4 \mathrm{~h}$ after inoculation (fig. $7 \mathrm{~d}$ ). Moreover, the bacterial counts in blood from those mice that had bacteremia were significantly lower in the $\mathrm{SpA}^{-}$mutant-inoculated group compared with the $S$. aureus-inoculated group (fig. 7e). Taken together, these results suggest that $S$. aureus, via protein A, regulates the expression of IL1 RII and IL- $1 \beta$ availability, therefore modulating the subsequent inflammatory status during early systemic infection and contributing to the bacterial persistence in blood.

\section{Discussion}

The role that cytokine decoy receptors play under physiological conditions has been explored during the last decade [10]. Their function under pathological conditions and during infectious diseases in particular is more intriguing. There is experimental evidence supporting the requirement of IL- $1 \beta$ to promote neutrophil recruitment and bacterial clearance during the early phase of $S$. aureus infection [4]; however, elevated levels of the decoy receptor IL-1RII are found in the circulation of septic patients caused by Gram-negative and Gram-positive bacteria $[5,35]$ and they are usually associated with poor patient outcome $[5,35]$. In the present study, we demon-

S. aureus Induces IL-1RII Shedding strated that $S$. aureus and protein A induce the early shedding of IL-1RII in myeloid cells. Receptor cleavage preceded the detection of IL- $1 \beta$ in vitro. The results obtained using an $\mathrm{SpA}^{-}$mutant suggest that the masking of detectable IL- $1 \beta$ induced by $S$. aureus both in vitro and in vivo could be due to the induction of IL-1RII expression and the presence of its soluble form in the extracellular medium. The early induction of IL-1RII during systemic $S$. aureus infection was associated with decreased levels of inflammatory cytokines and chemokines, as well as an increased bacterial persistence in blood.

ADAM17 along with other proteases is proposed to be involved in the release of membrane-bound IL-1RII [11, $12,14]$. Similar to our previous results regarding the cleavage of TNFR1 from airway epithelial cells and macrophages $[19,22]$, our present results suggest that protein A induces the cleavage of IL-1RII mainly through the action of ADAM17, which is activated via EGFR-mediated signaling. We observed, however, residual cleavage of IL1RII in the presence of TAPI-I suggesting the putative involvement of other proteases. Moreover, considering that the inhibitor used may present certain nonspecific activities, it cannot be ruled out that the inhibition observed was partially due to the role of other metalloproteases. In this regard, it has been proposed that IL-1RII is proteolytically processed in a manner similar to the amyloid precursor protein by which the receptor first undergoes ectodomain shedding in an $\alpha$-secretase-like manner, resulting in secretion of the IL-1RII ectodomain and the generation of an IL-1RII C-terminal fragment. This fragment undergoes further intramembrane proteolysis by a $\gamma$-secretase, leading to the generation of the soluble intracellular domain of IL-1RII [15]. Moreover, in addition to the action of metalloproteinases, it has been described that the aminopeptidase regulator of TNFR1 shedding (ARTS-1) is required for IL-1RII shedding [10]. The relative contribution of the above-described signaling pathways in the cleavage of IL-1RII induced by protein A remains to be elucidated. Induction of ADAM17 activity by several molecules, including bacterial antigens, has been reported [13]. The cellular targets of this metalloprotease are extremely diverse and the signaling cascades that link a certain stimuli with the action of ADAM17 on a specific target are poorly understood. Whereas liberation of TNF- $\alpha$ from the cell surface by ADAM17 induced by $S$. aureus depends on the recognition of several antigens and PAMPs, such peptidoglycan, $\delta$-hemolysin, protein A, lipoteichoic acid and teichoic acids [36], shedding of TNFR1 is highly dependent on protein A expression [19, 22]. Similarly, in this study we observed that the early 
shedding of IL-1RII from monocytes is dependent on protein A expression. Our results also suggest that either protein A is not able to activate ADAM17 in neutrophils or that in this cell type other proteases activated by antigens other than protein A may have a more prominent role in IL-1RII shedding.

The beneficial anti-inflammatory role of IL-1RII in different pathological conditions has been demonstrated using animal models and exogenous receptor administration [10]. Intravenous inoculation of sIL-1RII significantly reduced joint swelling and erosion in an arthritis model in rabbits [10], and gene transfer of a sIL-1RII-Ig fusion protein reduced allograft rejection and prolonged graft survival in a rat model of heart transplantation [10]. On the contrary, there is very little understanding about how the expression of endogenous IL-1RII and its shedding is regulated. IL-1RII expression has been described in human monocytes, neutrophils and keratinocytes, as well as in activated T and B cells [10]. Moreover, it has been recently demonstrated that mouse monocytes and neutrophils express IL-1RII under naive and inflammatory conditions [26]. Increased endogenous expression of sIL-1RII has been associated with diverse pathological conditions [10]. High levels of circulating sIL-1RII have been found in septic patients with a Gram-negative or Gram-positive infectious foci [35], as well as in necrotizing enterocolitis in preterm infants [10]. Moreover, during acute meningococcal infections, increased levels of sIL-1RII correlate with disease severity [10]. In an attempt to elucidate the molecular events that regulate IL$1 \beta$ signaling, previous studies have described that molecules with anti-inflammatory activity, such as glucocorticoids, IL-4 and IL-13, induce an increase in IL-1RII expression and shedding, providing an excess of available, surface-exposed and soluble decoy receptor that would serve to neutralize IL- $1 \beta$ signaling [10]. In support of the putative role of sIL-1RII in neutralizing IL- $1 \beta$ activity, it has been described that during endometriosis, a pathology for which IL- $1 \beta$ has a critical role in the development of the disease, a defective expression of IL-1RII contributes to pathogenesis [10]. Moreover, sIL-1-RII administered intraperitoneally reduced the expression of IL- $1 \beta$-dependent inflammatory, angiogenic and cell growth mediators in mice [10]. Proinflammatory molecules such as TNF- $\alpha$ and bacterial LPS also modulate IL1 RII expression and shedding to serve its own purpose. LPS causes rapid shedding of IL-1RII in human cells in vitro [37] and murine cells in vivo [26]. IL-1RII cleavage induced by LPS in vitro is associated with its transcription inhibition and increased expression of IL-1RI, sug- gesting that LPS-induced cleavage would function to deplete the cell from IL-1RII, thus increasing IL- $1 \beta$ signaling through IL-1RI [37]. In addition to the action of sIL-1RII, IL-1 $\beta$ activity may be interfered by the presence of the IL-1 receptor antagonist (IL-1Ra), a cytokine which competitively inhibits IL- $1 \beta$ by binding to IL-1RI without agonist activity [38]. Increased IL-1Ra concentrations have also been demonstrated in septic patients [38]. In this study we demonstrated that $S$. aureus and protein A induce rapid shedding of IL-1RII from the cell surface. In parallel, an increase in IL-1RII and IL-1Ra transcription was observed in peritoneal infiltrates from S. aureus-infected mice. Taken together, our results suggest that, in contrast to LPS-mediated responses, IL-1RII shedding induced by protein A could be part of an antiinflammatory program triggered by $S$. aureus. In this regard, it is important to note that not only $S$. aureus induced early shedding of IL-1RII in myeloid cells, but also the appearance of the soluble form of IL-1RII preceded IL- $1 \beta$ production. The presence of increased levels of IL$1 \beta$ found in peritoneal fluid and plasma from mice challenged with an $\mathrm{SpA}^{-}$mutant together with the absence of detectable IL-1 $\beta$ during the infection with wild-type $S$. aureus strongly suggest that early shedding of IL-1RII induced by protein A might constitute an evasion mechanism by which the bacteria modulates the activity of IL$1 \beta$, a cytokine known to be critical for its own eradication. These observations are in agreement with previous results that demonstrate a role for soluble TNFR1 in neutralizing circulating TNF- $\alpha$ and impairing the host inflammatory response during experimental $S$. aureus infection [22].

The critical role of inflammatory cytokines and chemokines in the eradication of $S$. aureus during systemic infections has been previously demonstrated $[3,4,39$, 40]. The in vivo results presented in this work show that mice challenged with $S$. aureus presented an attenuated inflammatory state characterized by local decreased levels of inflammatory cytokines, such as IL- 6 and IFN- $\gamma$, as well as CXCL1 compared with those inoculated with an $\mathrm{SpA}^{-}$mutant in which IL- $1 \beta$ was highly available. Moreover, protein A also contributed to the early induction of CXCL10, a chemokine known to participate in the resolution of inflammation [41]. The combined effect of decreased inflammatory mediators as a consequence of negative regulation on IL-1 $\beta$ availability and increased CXCL10 production in response to protein A resulted in the early recruitment of monocytes to the peritoneum in mice inoculated with $S$. aureus compared to those inoculated with the SpA- mutant. The early arrival of mono- 
cytes could contribute to accelerating the resolution of inflammation, as was evidenced by rapid CXCL1 downregulation to the detriment of bacterial eradication. Therefore, the higher rate of bacteremia observed in $S$. aureus-inoculated mice could be explained by both decreased bacterial killing in blood due to the low levels of TNF- $\alpha$ and IL- $1 \beta$, cytokines critical for neutrophil activation, and increased leaking of bacteria from the peritoneum. In this regard, the importance of CXCL1 and neutrophils in the eradication of bacteria from the peritoneum, preventing systemic dissemination, has been previously demonstrated [42].

Taken together, our findings indicate that in addition to the induction of soluble cytokine receptors [22,24], S. aureus may subvert other physiological control mechanisms via the induction of decoy receptors such as IL1 RII. The ability of $S$. aureus to downregulate the avail- ability of cytokines known to be critical for bacterial eradication constitutes a novel mechanism of immune evasion by this microorganism.

\section{Acknowledgements}

This work was supported by grants from the Agencia Nacional de Promoción de la Ciencia y la Tecnología, Argentina (PICT 2010-2152, PICT 2011-2263 and PICT 2013-1233 to M.I.G.; PICT 2013-0941 to D.O.S.) and the Secretaría de Ciencia y Técnica, Universidad de Buenos Aires, Buenos Aires, Argentina (UBACyT 20020110100138 to M.I.G.; 20020130100331 BA to D.O.S.). We thank Daniela Ureta for her technical assistance with flow cytometry.

\section{Disclosure Statement}

The authors have no conflicts of interest to declare.

\section{References}

1 Lowy FD: Staphylococcus aureus infections. N Engl J Med 1998;339:520-532.

-2 Rasmussen RV, Fowler VG Jr, Skov R, Bruun NE: Future challenges and treatment of Staphylococcus aureus bacteremia with emphasis on MRSA. Future Microbiol 2011;6: 43-56.

-3 Hultgren OH, Svensson L, Tarkowski A: Critical role of signaling through IL-1 receptor for development of arthritis and sepsis during Staphylococcus aureus infection. J Immunol 2002;168:5207-5212.

-4 Miller LS, Pietras EM, Uricchio LH, Hirano K, Rao S, Lin H, O'Connell RM, Iwakura Y, Cheung AL, Cheng G, Modlin RL: Inflammasome-mediated production of IL- $1 \beta$ is required for neutrophil recruitment against Staphylococcus aureus in vivo. J Immunol 2007;179:6933-6942.

5 Pruitt JH, Welborn MB, Edwards PD, Harward TR, Seeger JW, Martin TD, Smith C, Kenney JA, Wesdorp RI, Meijer S, Cuesta MA, Abouhanze A, Copeland EM 3rd, Giri J, Sims JE, Moldawer LL, Oldenburg HS: Increased soluble interleukin-1 type II receptor concentrations in postoperative patients and in patients with sepsis syndrome. Blood 1996; 87:3282-3288.

6 van den Berg S, Laman JD, Boon L, ten Kate MT, de Knegt GJ, Verdijk RM, Verbrugh HA, Nouwen JL, Bakker-Woudenberg IA: Distinctive cytokines as biomarkers predicting fatal outcome of severe Staphylococcus aureus bacteremia in mice. PLoS One 2013; 8:e59107.

7 Waage A, Brandtzaeg P, Halstensen A, Kierulf $\mathrm{P}$, Espevik T: The complex pattern of cytokines in serum from patients with menin- gococcal septic shock: association between interleukin 6, interleukin 1, and fatal outcome. J Exp Med 1989;169:333-338.

-8 Garlanda C, Dinarello CA, Mantovani A: The interleukin-1 family: back to the future. Immunity 2013;39:1003-1018.

-9 Sims JE, Gayle MA, Slack JL, Alderson MR, Bird TA, Giri JG, Colotta F, Re F, Mantovani A, Shanebeck K, et al: Interleukin 1 signaling occurs exclusively via the type I receptor. Proc Natl Acad Sci USA 1993;90:6155-6159.

10 Garlanda C, Riva F, Bonavita E, Gentile S, Mantovani A: Decoys and regulatory 'receptors' of the IL-1/toll-like receptor superfamily. Front Immunol 2013;4:180.

11 Orlando S, Sironi M, Bianchi G, Drummond $\mathrm{AH}$, Boraschi D, Yabes D, Mantovani A: Role of metalloproteases in the release of the IL-1 type II decoy receptor. J Biol Chem 1997;272: 31764-31769.

12 Lorenzen I, Lokau J, Dusterhoft S, Trad A, Garbers C, Scheller J, Rose-John S, Grotzinger $\mathrm{J}$ : The membrane-proximal domain of a disintegrin and metalloprotease 17 (ADAM17) is responsible for recognition of the interleukin-6 receptor and interleukin-1 receptor II. FEBS Lett 2012;586:1093-1100.

13 Gooz: ADAM-17: the enzyme that does it all. Crit Rev Biochem Mol Biol 2010;45:146-169.

14 Reddy P, Slack JL, Davis R, Cerretti DP, Kozlosky CJ, Blanton RA, Shows D, Peschon JJ, Black RA: Functional analysis of the domain structure of tumor necrosis factor- $a$ converting enzyme. J Biol Chem 2000;275:1460814614.

15 Kuhn PH, Marjaux E, Imhof A, De Strooper B, Haass C, Lichtenthaler SF: Regulated intramembrane proteolysis of the interleukin-1 re- ceptor II by $\alpha$-, $\beta$-, and $\gamma$-secretase. J Biol Chem 2007;282:11982-11995.

16 Sasso EH, Silverman GJ, Mannik M: Human IgM molecules that bind staphylococcal protein A contain VHIII H chains. J Immunol 1989;142:2778-2783.

17 Silverman GJ, Goodyear CS: Confounding Bcell defences: lessons from a staphylococcal superantigen. Nat Rev Immunol 2006;6:465475 .

18 Hartleib J, Kohler N, Dickinson RB, Chhatwal GS, Sixma JJ, Hartford OM, Foster TJ, Peters G, Kehrel BE, Herrmann M: Protein A is the von Willebrand factor binding protein on Staphylococcus aureus. Blood 2000;96:21492156.

19 Gomez MI, Lee A, Reddy B, Muir A, Soong G, Pitt A, Cheung A, Prince A: Staphylococcus aureus protein A induces airway epithelial inflammatory responses by activating TNFR1. Nat Med 2004;10:842-848.

20 Martin FJ, Gomez MI, Wetzel DM, Memmi G, O'Seaghdha M, Soong G, Schindler C, Prince A: Staphylococcus aureus activates type I IFN signaling in mice and humans through the $\mathrm{Xr}$ repeated sequences of protein A. J Clin Invest 2009;119:1931-1939.

21 Gomez MI, Seaghdha MO, Prince AS: Staphylococcus aureus protein A activates TACE through EGFR-dependent signaling. EMBO J 2007;26:701-709.

22 Giai C, Gonzalez C, Ledo C, Garofalo A, Di Genaro MS, Sordelli DO, Gomez MI: Shedding of tumor necrosis factor receptor 1 induced by protein A decreases tumor necrosis factor alpha availability and inflammation during systemic Staphylococcus aureus infection. Infect Immun 2013;81:4200-4207. 
23 Gomez MI, O'Seaghdha M, Magargee M, Foster TJ, Prince AS: Staphylococcus aureus protein A activates TNFR1 signaling through conserved IgG binding domains. J Biol Chem 2006;281:20190-20196.

24 Gomez MI, Sokol SH, Muir AB, Soong G, Bastien J, Prince AS: Bacterial induction of TNF- $\alpha$ converting enzyme expression and IL-6 receptor $\alpha$ shedding regulates airway inflammatory signaling. J Immunol 2005; 175 : 1930-1936.

25 Alvarez ME, Fuxman Bass JI, Geffner JR, Fernandez Calotti PX, Costas M, Coso OA, Gamberale R, Vermeulen ME, Salamone G, Martinez D, Tanos T, Trevani AS: Neutrophil signaling pathways activated by bacterial DNA stimulation. J Immunol 2006;177:4037-4046.

26 Martin P, Palmer G, Vigne S, Lamacchia C, Rodriguez E, Talabot-Ayer D, Rose-John S, Chalaris A, Gabay C: Mouse neutrophils express the decoy type 2 interleukin-1 receptor (IL-1R2) constitutively and in acute inflammatory conditions. J Leukoc Biol 2013;94: 791-802.

27 Harikumar KB, Yester JW, Surace MJ, Oyeniran C, Price MM, Huang WC, Hait NC, Allegood JC, Yamada A, Kong X, Lazear HM, Bhardwaj R, Takabe K, Diamond MS, Luo C, Milstien S, Spiegel S, Kordula T: K63-linked polyubiquitination of transcription factor IRF1 is essential for IL-1-induced production of chemokines CXCL10 and CCL5. Nat Immunol 2014; 15:231-238.

28 Kogan-Sakin I, Cohen M, Paland N, Madar S, Solomon H, Molchadsky A, Brosh R, Buganim Y, Goldfinger N, Klocker H, Schalken JA, Rotter V: Prostate stromal cells produce
CXCL-1, CXCL-2, CXCL-3 and IL-8 in response to epithelia-secreted IL-1. Carcinogenesis 2009;30:698-705.

29 Hunter CA, Chizzonite R, Remington JS: IL-1 beta is required for IL-12 to induce production of IFN-gamma by NK cells: a role for IL-1 beta in the T cell-independent mechanism of resistance against intracellular pathogens. J Immunol 1995;155:4347-4354.

30 Wesa AK, Galy A: IL-1 beta induces dendritic cells to produce IL-12. Int Immunol 2001;13: 1053-1061.

31 Garofalo A, Giai C, Lattar S, Gardella N, Mollerach M, Kahl BC, Becker K, Prince AS, Sordelli DO, Gomez MI: The length of the Staphylococcus aureus protein A polymorphic region regulates inflammation: impact on acute and chronic infection. J Infect Dis 2012; 206:81-90.

32 Yeruva S, Ramadori G, Raddatz D: NF-кBdependent synergistic regulation of CXCL10 gene expression by IL- $1 \beta$ and IFN- $\gamma$ in human intestinal epithelial cell lines. Int J Colorectal Dis 2008;23:305-317.

33 Tomasdottir V, Vikingsson A, Hardardottir I, Freysdottir J: Murine antigen-induced inflammation - a model for studying induction, resolution and the adaptive phase of inflammation. J Immunol Methods 2014;415:36-45.

34 Remick DG, Bolgos GR, Siddiqui J, Shin J, Nemzek JA: Six at six: interleukin-6 measured $6 \mathrm{~h}$ after the initiation of sepsis predicts mortality over 3 days. Shock 2002;17:463-467.

35 Muller B, Peri G, Doni A, Perruchoud AP, Landmann R, Pasqualini F, Mantovani A: High circulating levels of the IL-1 type II decoy receptor in critically ill patients with sep- sis: association of high decoy receptor levels with glucocorticoid administration. J Leukoc Biol 2002;72:643-649.

36 Fournier B, Philpott DJ: Recognition of Staphylococcus aureus by the innate immune system. Clin Microbiol Rev 2005;18:521-540.

37 Penton-Rol G: Bacterial lipopolysaccharide causes rapid shedding, followed by inhibition of mRNA expression, of the IL-1 type II receptor, with concominant up-regulation of type I receptor and induction of incompletely spliced transcripts. J Immunol 1999;162:2931-2938.

38 Fischer E, van Zee KJ, Marano MA, Rock CS, Kenney JS, Poutsiaka DD, Dinarello CA, Lowry SF, Moldawer LL: Interleukin-1 receptor antagonist circulates in experimental inflammation and in human disease. Blood 1992;79:2196-2200.

-39 Abraham E: Why immunomodulatory therapies have not worked in sepsis. Intensive Care Med 1999;25:556-566.

40 Nakane A, Okamoto M, Asano M, Kohanawa M, Minagawa T: Endogenous gamma interferon, tumor necrosis factor, and interleukin-6 in Staphylococcus aureus infection in mice. Infect Immun 1995;63:1165-1172.

41 Vazirinejad R, Ahmadi Z, Kazemi Arababadi M, Hassanshahi G, Kennedy D: The biological functions, structure and sources of CXCL10 and its outstanding part in the pathophysiology of multiple sclerosis. Neuroimmunomodulation 2014;21:322-330.

42 Craciun FL, Schuller ER, Remick DG: Early enhanced local neutrophil recruitment in peritonitis-induced sepsis improves bacterial clearance and survival. J Immunol 2010;185: 6930-6938. 